\begin{tabular}{|c|c|c|}
\hline Beitr. Ent. & Berlin & ISSN 0005-805X \\
\hline $\mathbf{5 0}(2000) 1$ & S. $193-198$ & 11.04 .2000 \\
\hline
\end{tabular}

\title{
The Chromosomes of three species of the Nasonia complex
}

\section{(Hymenoptera, Pteromalidae)}

With 1 figure and 2 tables

VLADIMIR E. GOKHMAN \& MAGDALENE WESTENDORFF

\section{Summary}

The karyotypes of three sibling species, Nasonia vitripennis (WALKER, 1836), N. longicornis DARLING, 1990 and $N$. giraulti DARLING, 1990 were examined, the latter two species for the first time. All species have chromosome numbers of $n=5$ and $2 n=10$, their chromosomes being metacentric. The distribution of constitutive heterochromatin also appears to be similar in the genus Nasonia ASHMEAD, 1904. However, statistical karyotypic differences between studied species were revealed using chromosome morphometrics. These data are consistent with the order of divergence in the Nasonia complex found on the basis of molecular studies.

\section{Zusammenfassung}

Die Ergebnisse der Untersuchung des Karyotyps der Schwesterarten Nasonia vitripennis (WALKER, 1836), $N$. longicornis DARLING, 1990 und $N$. giraulti DARLING, 1990 werden mitgeteilt. Für die beiden letztgenannten Arten liegen bisher keine karyologischen Daten vor. Die Karyotypen der drei untersuchten Arten mit $n=5$ und $2 n=10$ bestehen aus metacentrischen Chromosomen. Die Verteilung des konstitutiven Chromatins scheint in der Gattung Nasonia ASHMEAD, 1904 ebenfalls sehr einheitlich zu sein. Demgegenüber ergab die Morphometrie der Chromosomen statistisch signifikante Unterschiede zwischen den drei Arten. Die vorliegenden Daten entsprechen der Abfolge der Artenspaltungen im Nasonia-Komplex, die auf der Basis molekulargenetischer Untersuchungen festgestellt wurde.

\section{Резиме}

Исследованы кариотипы трех видов-двойников, Nasonia vitripennis (WALKER, 1836), N. longicornis DARLING, 1990 и $N$. giraulti, 1990, причем два последних вида изучены впервые. У всех трех наездников $\mathrm{n}=5$ и $2 \mathrm{n}=10$, и в их кариотипах присутствуют только метацентрические хромосомы. В пределах рода Nasonia ASHMEAD, 1904 распределение конститутивного гетерохроматина также является весьма сходным. Однако, с помощью морфометрических методов между хромосомными наборами рассматриваемых видов выявлены статистически достоверные отличия. Эти результаты соответствуют порядку дивергенции в комплексе Nasonia, определеннему по данным молекулярно-генетических исследований.

Nasonia vitripennis (WALKER, 1836) is a well-known cosmopolitan parasite of cyclorrhaphous diptera (BOUČEK \& RASPLUS, 1991). Various aspects of its biology have been extensively investigated all over the world (e.g. WHITING, 1967; VAN DEN ASSEM,1976; WERREN, 1983). This species was widely used in genetic research, a limited genomic map based on visible 
markers is available (SAUL, 1990). First data on its chromosome number, $n=5$, were obtained by GERSHENZON (1946) and later confirmed by other studies (PENNYPACKER, 1958; GERSHENZON, 1968; WHITING, 1968; NUR et al., 1988). The only detailed karyotypic description of $N$. vitripennis was made by REED (1993) who provided data on chromosome morphometrics as well as on C- and Ag-NOR-bandings in this species.

The genus Nasonia ASHMEAD, 1904 was considered to be monotypic for many years. Surprisingly enough, two new sibling species, $N$. longicornis DARLING, 1990 and $N$. giraulti DARLING, 1990 were found in this genus in North America about ten years ago (DARLING \& WERREN, 1990). An extensive study of this complex revealed a number of morphological characters which could be used as distinction features for these taxa. In addition, many other characters could be used for separating these species with $0.95-0.999 \%$ certainty. Furthermore, $N$. vitripennis, $N$. longicornis and $N$. giraulti substantially differ in their courtship behaviour (VAN DEN ASSEM \& WERREN, 1994).

Chromosome number and other karyotypic features of the Pteromalidae appear to be highly conservative. Specifically, eight studied species of the family have $n=5$ (GOKHMAN \& QUICKE, 1995; GOKHMAN, in press). Except for $N$. vitripennis, neither morphometric studies of karyotypes nor differential chromosome staining in these species, however, were performed to date. Moreover, $\mathfrak{n}=6$ was found in a local population of $N$. vitripennis from California (GOODPASTURE, 1974). Even among laboratory stocks of this species normally having $n=5$, some populations carrying a particular B chromosome were revealed (NUR et al., 1988; WERREN, 1991). The present paper deals with the results of a karyological study of $N$. vitripennis, $N$. longicornis and $N$. giraulti using routine and differential (C-) chromosome staining.

\section{Material and methods}

Chromosomes of all three Nasonia species were studied in wasps from laboratory cultures maintained at the Institute of Evolutionary and Ecological Sciences, University of Leiden, namely: Lab II, a laboratory stock of Nasonia vitripennis originally collected in Leiden more than 20 years ago; strain IV7 R2 of $N$. longicornis derived from the strain IV7 (nest UT007) which had been collected in Utah, USA, in July 1988; and strain R16A of $N$. giraulti derived from a particular strain (nest VA002) which had been collected in Virginia, USA, in September 1988. Air-drying chromosome preparations were made from cerebral ganglia of male and female prepupae, according to the routine procedure described by IMAI et al. (1988). Differential chromosome staining (C-banding) was performed according to the method developed by SUMNER (1972) and modified by GOKHMAN (1997). Chromosomes were studied under microscopes MBR-15 and Zeiss NU-2. For making chromosome measurements, ten diploid metaphase plates for each species were scanned using static TV camera equipped with the image analysis program ImageExpert version 1.00. Scanned images were measured using Adobe Photoshop version 3.0.5. Statistical data analysis was performed with the help of STATISTICA version 4.3.The $t$ test for independent samples was used as a statistical criterion.

\section{Results}

Numbers of studied individuals and metaphase plates for each species are presented in Table 1. Relative lengths and centromeric indices of all chromosomes of the three species are shown in Table 2. Chromosomes of $N$. vitripennis, $N$. longicornis and $N$. giraulti are very similar, especially for their centromeric indices. Due to this similarity, a unified karyotypic description is given for all species, with interspecific differences being added. 
Tab. 1: Number of studied individuals of the Nasonia complex and their metaphase plates.

\begin{tabular}{|l|c|c|c|c|}
\hline \multirow{2}{*}{ Species } & \multicolumn{2}{|c|}{ No. of individuals } & \multicolumn{2}{c|}{ No of metaphase plates } \\
\cline { 2 - 5 } & males & females & haploid & diploid \\
\hline N. vitripennis (WALKER, 1836) & 1 & 9 & 20 & 15 \\
\hline N. longicornis DARLING, 1990 & 1 & 9 & 2 & 37 \\
\hline N. giraulti DARLING, 1990 & 1 & 8 & 10 & 41 \\
\hline
\end{tabular}

Tab. 2: Relative length (RL) and centromeric index (CI) of chromosomes of the Nasonia complex. Values having a common superscript significantly differ: ${ }^{a}$ at $p<0.001,{ }^{\text {bc }}$ at $p<0.05$.

\begin{tabular}{|l|c|c|c|c|c|c|}
\hline \multirow{2}{*}{$\begin{array}{l}\text { Chr. } \\
\text { no. }\end{array}$} & \multicolumn{5}{|c|}{ Species } \\
\cline { 2 - 7 } & \multicolumn{2}{|c|}{$N$. vitripennis } & \multicolumn{2}{|c|}{ N. longicornis } & \multicolumn{2}{c|}{ N. giraulti } \\
\cline { 2 - 7 } & $\mathrm{RL}$ & $\mathrm{CI}$ & $\mathrm{RL}$ & $\mathrm{CI}$ & $\mathrm{RL}$ & $\mathrm{CI}$ \\
\hline 1 & $25.97 \pm 1.44$ & $46.93 \pm 2.64$ & $25.48 \pm 0.82$ & $46.82 \pm 2.68$ & $25.58 \pm 1.28$ & $46.89 \pm 1.83$ \\
\hline 2 & $21.03 \pm 0.63^{\mathrm{ab}}$ & $47.52 \pm 2.29$ & $21.84 \pm 0.63^{\mathrm{a}}$ & $46.65 \pm 2.27$ & $21.59 \pm 0.85^{\mathrm{b}}$ & $46.27 \pm 2.01$ \\
\hline 3 & $19.59 \pm 0.74$ & $47.37 \pm 2.68$ & $19.80 \pm 0.70^{\mathrm{c}}$ & $46.66 \pm 2.94$ & $19.34 \pm 0.72^{\mathrm{c}}$ & $46.92 \pm 2.15$ \\
\hline 4 & $17.71 \pm 0.81$ & $46.88 \pm 2.47$ & $17.57 \pm 0.49$ & $45.22 \pm 3.21$ & $17.78 \pm 0.64$ & $46.84 \pm 2.51$ \\
\hline 5 & $15.70 \pm 0.67$ & $46.97 \pm 2.20$ & $15.32 \pm 0.97$ & $46.20 \pm 3.46$ & $15.71 \pm 1.18$ & $46.07 \pm 2.50$ \\
\hline
\end{tabular}

The same chromosome numbers, $\mathrm{n}=5$ and $2 \mathrm{n}=10$, were found in $N$. vitripennis, $N$. longicornis and $N$. giraulti, all chromosomes being obviously metacentric and gradually decreasing in size (Figs. 1-3). The first chromosome pair is slightly larger than the others. Chromosome 2 is significantly shorter in $N$. vitripennis than in $N$. giraulti or $N$. longicornis. Similarly, chromosome 3 is longer in the latter species than in $N$. giraulti.

The distribution of the constitutive heterochromatin also appeared quite similar in the three Nasonia species. All chromosomes have characteristic large segments of centromeric heterochromatin. Moreover, the shorter arm of the chromosome 3 is also heterochromatic, at least in most of the metaphase plates (Figs. 4-6).

\section{Discussion}

All karyotypes of the Nasonia complex are symmetrical and very much similar to each other. However, they differ from chromosome sets of some other Pteromalidae also having $\mathrm{n}=5$. Unfortunately, these differences can usually be revealed only after making detailed chromosome measurements. For example, one of the two species belonging to the Anisopteromalus calandrae (HOWARD, 1881) species complex also has $\mathrm{n}=5$ (GOKHMAN et al., 1998), but its haploid karyotype is more asymmetrical, with two smaller chromosomes being visibly shorter than the third one. Moreover, the smallest chromosome of the latter species is submetacentric, whereas the others are clearly metacentric. 

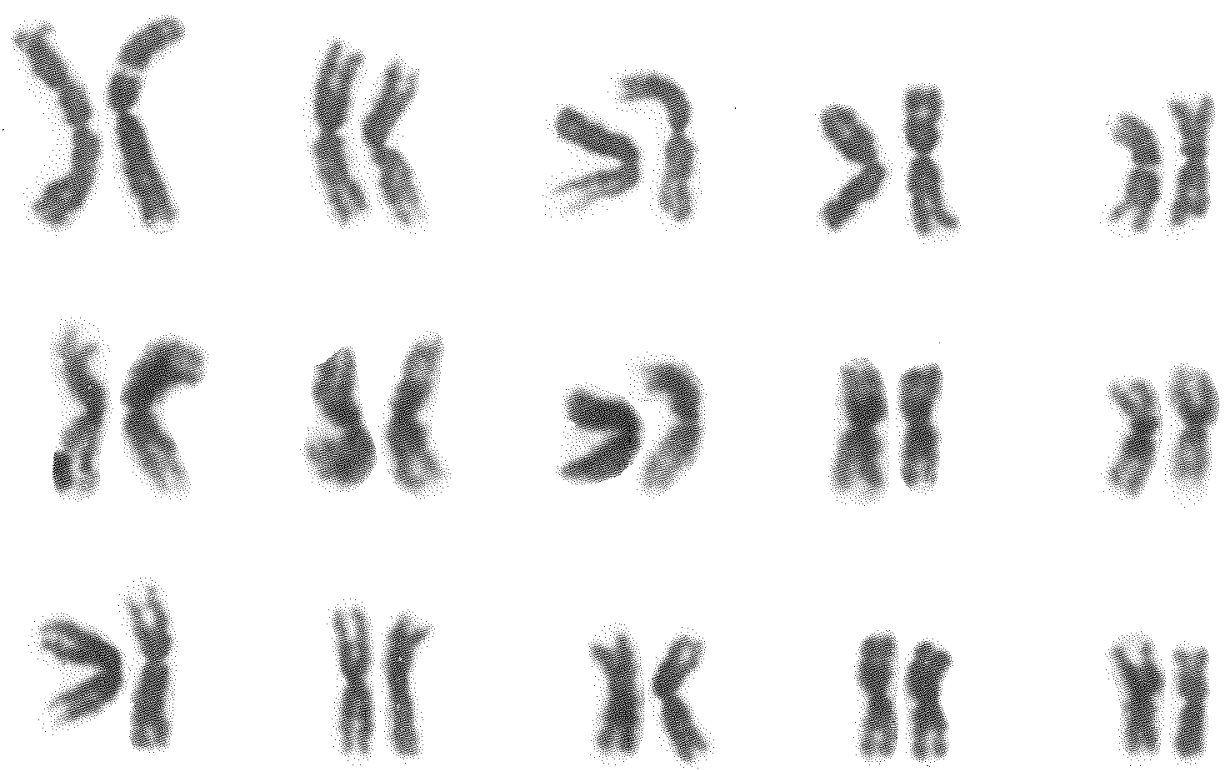

(3)
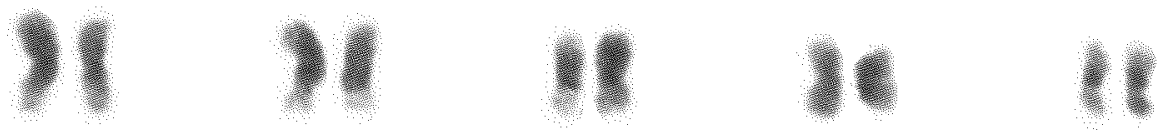

(4)
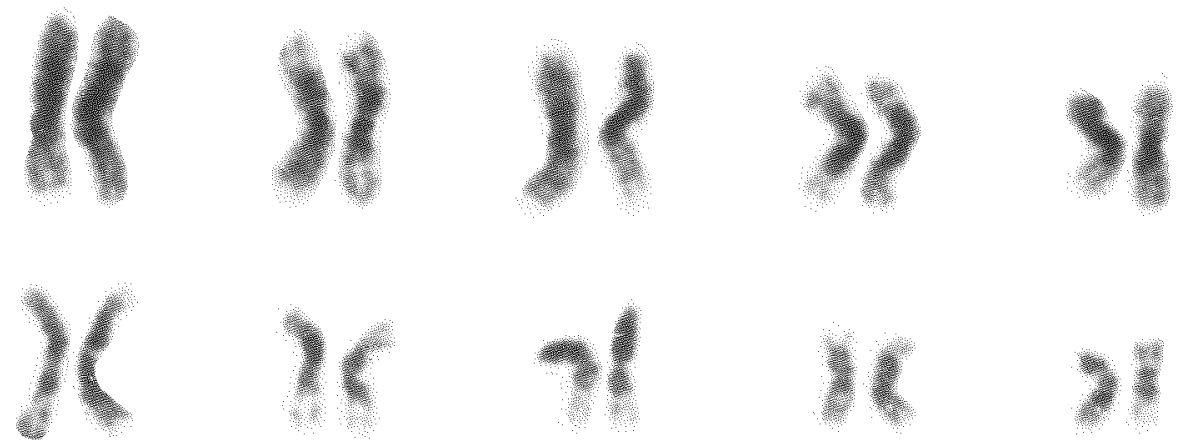

Figs 1-6. Diploid karyotypes of Nasonia species. Figs 1-3. Routine staining. $1-N$. vitripennis, $2-N$. longicornis, $3-N$. giraulti. Figs 4-6. Differential C-banding. $4-N$. vitripennis, $5-N$. longicornis, $6-N$. giraulti. Bar equals $10 \mu \mathrm{m}$. 
Our data on relative chromosome lengths in $N$. vitripennis are very close to those calculated by REED (1993), namely: 25.10, 21.36, 19.74, 17.89 and 15.91 (transformed from absolute chromosome lengths). The latter author was also able to demonstrate the presence of pericentromeric heterochromatin in all chromosomes of this wasp species.

Evidence obtained from the study of an rDNA internal transcribed spacer (ITS2) (CAMPBELL et al., 1993) and mitochondrial 16S DNA of the Nasonia complex (REED \& WERREN, in litt.) suggests that the time of divergence between $N$. vitripennis and the two remaining species is approximately 200,000 years, and that between $N$. longicornis and $N$. giraulti is about 100,000 years. Our data are consistent with the order of divergence in the Nasonia complex found on the basis of molecular studies. Specifically, a comparison of relative lengths of the chromosome 2 demonstrates that $N$. vitripennis is likely to stem out first from the common lineage which split later into $N$. longicornis and $N$. giraulti. The significant difference on the relative lengths of chromosome 3 between the two latter species may reflect an autapomorphous chromosomal rearrangement occurred in one of these taxa.

\section{Acknowledgements}

The authors are very grateful to Dr. JOHN WERREN (University of Rochester, NY) and Dr. LEO BEUKEBOOM (University of Leiden, The Netherlands) for providing living material for the chromosomal study and also to Dr. ANDREY G. DEVYATOV (Moscow State University, Moscow, Russia) for technical assistance. This study was partly supported by the Deutscher Akademischer Austauschdienst, Bonn (V. E. GOKHMAN),

\section{References}

ASSEM, J. VAN DEN 1976: Male courtship behaviour, female receptivity signal, and size differences between sexes in Pteromalinae (Hym. Chalcidoidea Pteromalidae), and comparative notes on other chalcidoids. - Neth. J. Zool. 26: 535-548.

ASSEM, J. VAN DEN \& WERREN J. H. 1994: A comparison of the courtship and mating behavior of three species of Nasonia (Hymenoptera: Pteromalidae). - J. Insect Behav. 7: 53-66.

BOUČEK, Z. \& RASPLUS J.-Y. 1991: Illustrated key to West-Palearctic genera of Pteromalidae (Hymenoptera: Chalcidoidea). - Inst. National Rech. Agr. Paris. 140 pp.

CAMPBell, B. C.; STefFen-CAMPBell J. D. \& WerRen J. H. 1993: Phylogeny of the Nasonia species complex (Hymenoptera: Pteromalidae) inferred from an internal transcribed spacer (ITS2) and 28S rDNA sequences. - Insect Mol. Biol. 2: 255-237.

DARLING, D. C. \& Werren J. H. 1990: Biosystematics of Nasonia (Hymenoptera: Pteromalidae): Two new species reared from birds' nests in North America. - Ann. Entomol. Soc. Amer. 83: 352-370.

GERSHENZON, S. M. 1946: The genetic structure of the natural populations of Mormoniella vitripennis WLK. (Chalcididae: Hymenoptera). - Zh. Obshchei Biol. 7: 165-173 (in Russ.).

GERSHENZON, S. M. 1968: The chromosomes and sex determination in the parasitic wasp, Mormoniella vitripennis WALKER. - Tsitologiya i Genetika 2 (1): 3-13 (in Russ.).

GOKHMAN, V. E. 1997: Differential chromosome staining in parasitic wasps of the genus Dirophanes (Hymenoptera, Ichneumonidae). - Zool. Zhurnal 76 (1): 65-68 (in Russ.).

GOKHMAN, V.E. (in press). Karyology of parasitic Hymenoptera: Current state and perspectives. - In: $4^{\text {th }}$ Intern. Hymen. Conf. 6-11 th Jan. 1999. Canberra, Australia. Contributed Papers.

GOKHMAN, V.E. \& QUICKE D. L. J. 1995: The last twenty years of parasitic Hymenoptera karyology: An update and phylogenetic implications. - J. Hym. Res. 4: 41-63.

GokHMAN, V. E.; Timokhov A. V. \& FedNA T. YU. 1998: First evidence for sibling species in Anisopteromalus calandrae (Hymenoptera: Pteromalidae). - Russ. Entomol. J. 7 (3-4): 157-162.

GOODPASTURE, C. 1974: Cytological data and classification of the Hymenoptera. - Unpublished Ph.D. thesis. Univ. of California, Davis. 178 pp. 
IMAI, H. T.; TAYLOR R. W.; Crosland M. W. J. \& CROzIER R. H. 1988: Modes of spontaneous chromosomal mutation and karyotype evolution in ants with reference to the minimum interaction hypothesis. - Jpn. J. Genet. 63: 159-185.

Nur, U.; Werren J. H.; EickBUSH, D. G.; BURKE W. D. \& EICKBUSH T. H. 1988: A 'selfish' B chromosome that enhances its transmission by eliminating the paternal genome. - Science 240: 512-514.

PENNYPACKER, M. I. 1958: The chromosomes of the parasitic wasp Mormoniella vitripennis. Part I. In spermatogenesis of haploid and diploid males. - Arch. Biol. Liège 69: 483-495.

REED, K. M. 1993: Cytogenetic analysis of the paternal sex ratio chromosome of Nasonia vitripennis. Genome 36: 157-161.

SAUL, G. B. 1990: Gene map of the parasitic wasp Nasonia vitripennis (= Mormoniella vitripennis), $2 \mathrm{~N}$ $=10$. - In: S. J. O'Brien (Ed.). Genetic Maps. Locus Maps of Complex Genomes. Book 3. N.Y., Cold Spring Harbor Laboratory Press: 198-201.

SUMNER, A. T. 1972: A simple technique for demonstrating centromeric heterochromatin. - Exp. Cell Res. 75: 304-306.

WERREN, J. H. 1983: Sex ratio evolution under local mate competition in a parasitic wasp. - Evolution 37: 116-124.

WERREN, J. H. 1991: The paternal-sex-ratio chromosome of Nasonia. - Am. Nat. 137: 392-402.

WHITING, A.R. 1967: The biology of the parasitic wasp Mormoniella vitripennis [= Nasonia brevicornis] (WALKER). - Quart. Rev. Biol. 42: 333-406.

Whiting, P. W. 1968: The chromosomes of Mormoniella. - J. Heredity 59: 19-22.

\section{Authors ${ }^{6}$ addresses:}

VLADIMIR E. GOKHMAN

Botanical Garden

Moscow State University

119899 Moscow

Russia

e-mail: botsad@glas.apc.org

\section{MAGDALENE WESTENDORFF}

Deutsches Entomologisches Institut im Zentrum für Agrarlandschafts- und Landnutzungsforschung (ZALF)

Schicklerstraße 5 D - 16225 Eberswalde, Deutschland e-mail: westendorff@dei-eberswalde.de 